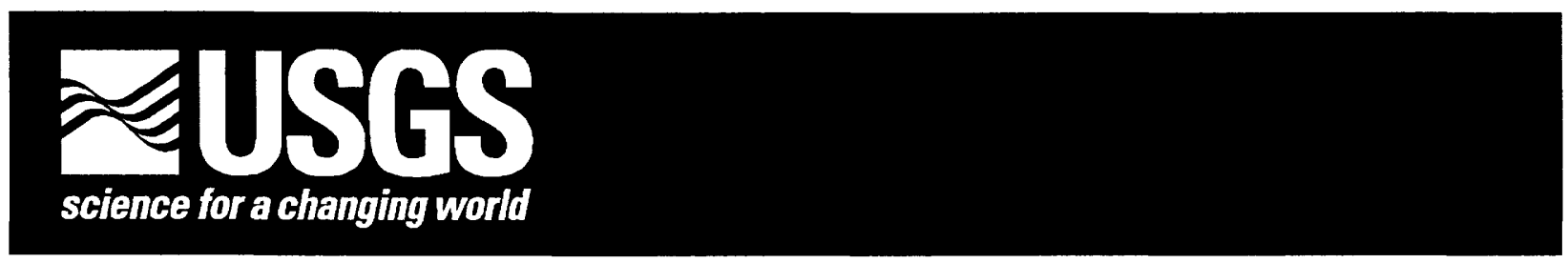

U.S. DEPARTMENT OF THE INTERIOR

GEOLOGIC QUADRANGLE MAP

U.S. GEOLOGICAL SURVEY

BELMONT WEST QUADRANGLE, NEVADA

GQ-1801

PAMPHLET

\title{
GEOLOGIC MAP OF THE BELMONT WEST QUADRANGLE, NYE COUNTY, NEVADA
}

By

\author{
Daniel R. Shawe
}

1998

\section{SUMMARY OF GEOLOGIC EVENTS}

The Cambrian marine clastic and carbonate rocks [Gold Hill ( $€ \mathrm{gs}, € \mathrm{gq}, € \mathrm{gl}, € \mathrm{glc}$, and $€ \mathrm{gsq}$ ) and Mayflower ( $€ \mathrm{~ms}$ ) Formations] in the Belmont West quadrangle were deposited as part of a westward-thickening wedge on the continental shelf at what was then the western edge of the North American continent (Stewart, 1980). Ordovician marine rocks (Toquima and Zanzibar Formations) were probably deposited as transitional facies rocks between predominantly carbonate-facies sediments on the continental shelf and siliceous facies sediments in a western ocean basin. Rocks of the Toquima Formation (Otq, Otl, Otlj, Otlc, Otla, Ota, Otal, and Ots) are more siliceous than those of the Zanzibar Formation (Ozl, Ozlc, Oza, Ozal, and Ozs), and they were intruded locally by mafic magma $(\mathrm{Og})$, and may have been deposited west of the Zanzibar.

Rocks of the Monarch area ( $P_{z} m a, P_{z} m g$, $P_{z m c}, P_{z m m}, P_{z} m d$, and $\left.P_{z m s}\right)$ are probably of Paleozoic age, but their specific age is unknown. Rocks of the southern facies may be of Cambrian age, on the basis of similarity of lithology of the argillite-chert unit $\left(\mathrm{P}_{\mathrm{Z}} \mathrm{ma}\right)$ with known Cambrian rocks in the region (F.G. Poole, oral commun., 1982). Whatever their age, it is clear they are of oceanic affinity. Greenstones ( $\mathrm{P}_{\mathrm{z}} \mathrm{mg}$ ) in both the southern and northern facies have high $\mathrm{TiO}_{2}$ contents, suggesting possible affinity to the Ordovician gabbro $(\mathrm{Og})$.

No sedimentary rocks of known late Paleozoic and Mesozoic age are present in the quadrangle lexcept for clasts of Permian Diablo Formation in the Oligocene megabreccia of Sloppy Gulch (Trls)], and the geologic history of the area during those eras is imperfectly known. On the basis of regional evidence, I surmise that the area underwent significant periodic compressional deformation starting in the late Paleozoic and continuing through the Mesozoic. The present configuration of the Cambrian and Ordovician thrust plates reflects such deformation: a lower plate of the Mayflower Schist is overlain on a strongly folded thrust fault by a plate of the Gold Hill Formation, which is in turn overlain by a plate of the Zanzibar Formation, which is overlain by a plate of the Toquima Formation. Deformation, both of the thrust faults and internally in the plates themselves, appears to diminish upward, suggesting that emplacement of the plates was successively from the base upward. Orientation and configuration of major folds in the Paleozoic rocks may have resulted from the shouldering effect of intrusion of the Cretaceous granite plutons ( $\mathrm{Kbgp}, \mathrm{Kbgs}$, $\mathrm{Kbg}, \mathrm{Kbgf}$, and $\mathrm{Kba}$; Kpg, Kpgd, and $\mathrm{Kpa}$ ), so the folds, mostly trending roughly parallel to pluton contacts, probably cannot be used to infer direction of thrust faulting. Thrust faulting probably continued into the Late Cretaceous, as evidenced by sheared granite sills emplaced along thrust faults in the Manhattan quadrangle west of the Belmont West quadrangle, and by the foliated Pipe Spring granite pluton (Kpg and Kpa), indicative of compressional deformation.

Rocks of the Monarch area ( $P_{z}$ ma, $P_{z} m g$, $P_{z} m c, P_{z} m m, P_{z} m d$, and $P_{z} m s$ ) underlie a thrust 
plate of Ordovician rocks, but their relation to other rocks in the quadrangle is unknown. They represent a prism of oceanic rocks obducted onto the continent sometime during Paleozoic or Mesozoic time. I have interpreted that a plate of upper Paleozoic rocks underlies the lower Paleozoic rocks in the Manhattan quadrangle, on the basis of the presence of fragments of Permian Diablo Formation in megabreccia (Trls) inferred to have erupted from depth below the Manhattan caldera (Shawe and Snyder, 1988; Shawe, 1998). Perhaps the rocks of the Monarch area are part of the same thrust plate.

Late Cretaceous granite plutons were emplaced during waning stages of compressional deformation. Initially, they probably formed thick lensoid sills intruded along major deepseated thrust breaks. The Belmont pluton (Kbgp, Kbgs, and $\mathrm{Kbg}$ ) was emplaced at about 85-84 Ma and the Pipe Spring pluton (Kpg) was emplaced at about $80 \mathrm{Ma}$; both plutons were invaded by aplites ( $\mathrm{Kba}$ and $\mathrm{Kpa}$ ), then domed and mineralized; the Belmont pluton was mineralized at about $80 \mathrm{Ma}$ and the Pipe Spring pluton at about $75 \mathrm{Ma}$. Some details of the mineralization were described by Shawe (1988).

Unlike the Round Mountain and Pipe Spring plutons (Shawe, 1995, 1998), the Belmont pluton shows little or no foliation parallel to intrusive contacts with Paleozoic rocks. It is foliated conspicuously only as generally steep, northwest-striking postmetamorphism shears probably related to strike-slip deformation on the margin of the northwest-striking Walker Lane tectonic zone to the southwest. On the other hand, a thin zone of mylonite, dipping subparallel to the contact of the Belmont pluton in the northeast corner of the quadrangle, may have resulted from deformation similar to that which formed foliation in the Round Mountain and Pipe Spring plutons. If deformation occurred when the Belmont pluton was nearly solidified following its emplacement, the strain may have been confined to a single plane (the thin mylonite zone). Conversely, if deformation of the Round Mountain and Pipe Spring plutons occurred while the plutons were still hot and plastic, strain may have been distributed through a wide zone, accounting for the broad zones of conspicuous foliation developed near the contacts of those plutons. Because of the similarity in some aspects (late-stage recurrent magmatism, metamorphic carapace, and, in the case of the Belmont pluton, a mylonite zone beneath the carapace) of the southern Toquima Range granite plutons and their wall rocks to metamorphic core complexes, further studies are warranted that could clarify the history, structure, and petrology of the Late Cretaceous southern Toquima igneous center.

Sometime before $27 \mathrm{Ma}$, the Big Ten Peak caldera formed southeast of the quadrangle, during emplacement of the quartz latite tuff (Tbql). A moat surrounding the caldera received first tuffaceous claystone, siltstone, and sandstone beds (Tcs), probably lacustrine, and subsequently freshwater limestone deposits (TI). A thick blanket of volcanic ash (Tat) from an unknown source (probably volcanoes related to the Big Ten Peak caldera), locally interrupted by lenses of fluvial conglomerate, was deposited next, at about $27 \mathrm{Ma}$. Ash flows from an eastern source probably in southeastern Nevada or southwestern Utah formed a thick layer (Til and Tiu) above the volcanic ash; these ash-flow tuffs superficially resemble the Isom Formation (Mackin, 1960; Anderson and Rowley, 1975; Best and others, 1989) and like the Isom were deposited at about $27 \mathrm{Ma}$. Their source and correlation are uncertain. The opaline silica tuff (Tos) was deposited on top of the Isom-type tuffs. Andesite plugs and flows (Tap) were emplaced at about 26.8-26.3 Ma in the moat of the Big Ten Peak caldera.

Eruption of silicic ash-flow tuffs of the Round Rock Formation (Trl, Trm, and Tru) and collapse of the Manhattan caldera occurred about $25 \mathrm{Ma}$. Emplacement of megabreccia units (Trls, Trm, and Trus) occurred throughout the history of caldera development. The megabreccia of Sloppy Gulch (Trls) was emplaced at intervals during early collapse of the Manhattan caldera and eruption of the lower member of the Round Rock Formation (Trl). Brecciated clasts in the megabreccia are unlike brecciated wall rocks, and Permian Diablo Formation that makes up some clasts in the megabreccia is unknown in the wall rocks. These clasts suggest a deep source beneath the caldera rather than a source in wall rocks, implying that the megabreccia of Sloppy Gulch was emplaced by eruption (Shawe and Snyder, 1988). The middle member of the Round Rock Formation (Trm), consisting of intermixed rhyolitic tuff, rhyolite, and andesite lava clasts in an ash-flow matrix, was emplaced as a relatively thin pyroclastic blanket of megabreccia throughout the Manhattan caldera. The megabreccia member is relatively thick only near an inferred volcanic neck of rhyolite similar to rhyolite clasts in the megabreccia. Andesite flow rock interpreted as deposits on the flank of the volcano is similar to andesite clasts in the megabreccia. The megabreccia blanket is inferred to have resulted from a catastrophic eruption of the composite rhyolite-andesite volcano, 
rather than from collapse of the volcano into the caldera. The megabreccia of Silver Creek (Trus) was emplaced near the end of the Round Rock cycle, having erupted along the northeast margin of the Manhattan caldera. Its eruptive nature, as evidenced by size sorting of large clasts outward from the inferred vent (Shawe and Snyder, 1988), is corroborated by presence of a thin outflow blanket that extends as far as $10 \mathrm{~km}$ to the east of the vent, at about the same elevation as the inferred orifice of the vent. (Additional details of the character and inferred origin of the megabreccia units are given in Shawe and Snyder, 1988.)

Tuff-breccia dikes (Trtb) that intrude the Round Rock Formation (Tru and Trls) at the southeast margin of the Manhattan caldera mark the probable location of a vent area for part of the megabreccia unit of Sloppy Gulch (Trls). Deposition of the Diamond King Formation ( $T d m$ and Tdu), correlated with the tuff of Arc Dome, at about $25 \mathrm{Ma}$ and from an inferred caldera on the west side of the Toiyabe Range and about $60 \mathrm{~km}$ to the northwest followed shortly thereafter. The Diamond King overlies the megabreccia of Silver Creek (Trus) as far as $10 \mathrm{~km}$ east of the inferred source of the megabreccia. The emplacement of a tuff-breccia dike (Trtb) into the Diamond King near the west margin of the quadrangle suggests some continuation of caldera activity following deposition of the Diamond King. Tuffaceous siltstones of the Bald Mountain Formation (Tbm), largely lacustrine, were deposited on the Diamond King Formation throughout the Manhattan caldera, suggesting that the caldera formed a basin at the time. Such a basin would seem enigmatic inasmuch as it would imply further collapse of the caldera following emplacement of the Round Rock Formation. However, the similarity in composition of the overlying tuff of The Bald Sister (Tbs) to tuffs in the Round Rock suggests a continuation of caldera activity following emplacement of the Diamond King and Bald Mountain Formations. John (1995) described somewhat analagous caldera subsidence that occurred following emplacement of major ash-flow tuffs within calderas in the Stillwater Range about $150 \mathrm{~km}$ to the northwest. Rhyolite plugs (Trr) intruded the megabreccia of Silver Creek at about $24.8 \mathrm{Ma}$, and the tuff of The Bald Sister (Tbs) was deposited on the Bald Mountain at about 24.8-24.6 Ma.

A stock and related sills and dikes of the Crone Gulch Andesite (Tca) were emplaced in the Bald Mountain Formation and older volcanic units in and near the Manhattan caldera probably at the time of deposition of the tuff of The
Bald Sister (24.8-24.6 Ma). Because I interpret the Crone Gulch as a product of resurgence of the caldera, my inference reinforces the interpretation that the tuff of The Bald Sister may be related to the Manhattan caldera.

The undevitrified ash-fall tuff (Tva) deposited near the mouth of Silver Creek at about $12.0 \pm 2.6 \mathrm{Ma}$ lies on a pedimented surface of the Belmont pluton (Kbgs; see cross section $\left.G-G^{\prime}\right)$. This relation suggests that Ralston Valley formed as a graben (or half graben, for Basin-range faults are evident only on the west side of the valley within the quadrangle) at least 10-15 Ma ago, and sufficient time elapsed following graben collapse for extensive erosion (pedimentation) into the head of the valley before deposition of the undevitrified ash-fall tuff. Because considerable alluviation of Ralston Valley occurred prior to pedimentation, it seems evident that the deeper parts of the valley fill are of late Tertiary age.

The older landslide $(Q \mid 1)$ on the north slope of the east-northeast-trending ridge in the southeast corner of the quadrangle probably formed during the wet period of the Pleistocene. The younger landslide $(\mathrm{Q} / 2)$ nearby, and other mapped landslides (QI), most on north-facing slopes, probably formed during a later, Holocene, period of increased moisture.

The channel of the main south-trending drainage in Ralston Valley, and prominent tributary channels such as those of East Manhattan and Bald Mountain Washes, and Silver Creek, are incised into older alluvium (Qa2a) as much as $10 \mathrm{~m}$. The main channel is as broad as $0.5 \mathrm{~km}$ whereas $10 \mathrm{~km}$ south of the Belmont West quadrangle the main channel is shallower and narrows to less than $100 \mathrm{~m}$. Evidently, erosion of the channel has been continuing longer in the Belmont West quadrangle than it has a few kilometers farther south. The relation indicates that the upper reaches of Ralston Valley, and consequently the adjacent ranges, were uplifted more recently relative to the terrane farther south. Differential uplift other than between range horsts and valley grabens in this part of the Basin-Range province is thus demonstrated.

\section{REFERENCES CITED}

Anderson, J.J., and Rowley, P.D., 1975, Cenozoic stratigraphy of southwestern high plateaus of Utah, in Anderson, J.J., Rowley, P.D., Fleck, R.J., and Nairn, A.E.M., eds., Cenozoic geology of southwestern high plateaus of Utah: Geological Society of America Special Paper 160, p. 1-51. 
Best, M.G., Christiansen, E.H., and Blank, R.H., Jr., 1989, Oligocene caldera complex and calc-alkaline tuffs and lavas of the Indian Peak volcanic field, Nevada and Utah: Geological Society of America Bulletin, v. 101, p. 1076-1090.

Brem, G.F., John, D.A., Nash, J.T., and Snyder, B.B., 1991, Mineral resources of the Arc Dome Wilderness Recommendation Area, Nye County, Nevada: U.S. Geological Survey Bulletin 1961, 21 p.

Ferguson, H.G., 1924, Geology and ore deposits of the Manhattan district, Nevada: U.S. Geological Survey Bulletin 723, 163 p.

Ferguson, H.G., and Cathcart, S.H., 1954, Geologic map of the Round Mountain quadrangle, Nevada: U.S. Geological Survey Geologic Quadrangle Map GQ-40, scale $1: 125,000$.

John, D.A., 1992, Stratigraphy, regional distribution, and reconnaissance geochemistry of Oligocene and Miocene volcanic rocks in the Paradise Range and northern Pactolus Hills, Nye County, Nevada: U.S. Geological Survey Bulletin 1974, 67 p.

1995, Tilted middle Tertiary ash-flow calderas and subjacent granitic plutons, southern Stillwater Range, NevadaCross sections of an Oligocene igneous center: Geological Society of America Bulletin, v. 107, p. 180-200.

John, D.A., and Robinson, A.C., 1989, Rb-Sr whole rock isotopic ages of granitic plutons in the western part of the Tonopah $1^{\circ}$ by $2^{\circ}$ quadrangle, Nevada: Isochron/West, no. 53, p. 20-27.

Keith, W.J., 1987a, Preliminary geologic map of the Big Ten Peak quadrangle, Nye County, Nevada: U.S. Geological Survey Open-File Report 87-7, scale 1:62,500.

1987b, Preliminary geologic map of the McCann 15-minute quadrangle, Nye County, Nevada: U.S. Geological Survey Open-File Report 87-425, scale 1:62,500.

1993, Megabreccia of the Big Ten Peak caldera, Nye County, Nevada: U.S. Geological Survey Open-File Report 93-21, 16 p.

Le Bas, M.J., Le Maitre, R.W., Streckeisen, A., and Zanettin, B.A., 1986, A chemical classification of volcanic rocks based on the total alkali-silica diagram: Journal of Petrology, v. 27, p. 745-750.

Mackin, J.H., 1960, Structural significance of Tertiary volcanic rocks in southwestern Utah: American Journal of Science, $v$. 258, p. 81-131.
McKee, E.H., 1968, Geology of the Magruder Mountain area, Nevada-California: U.S. Geological Survey Bulletin 1251-H, p. $\mathrm{H} 1-\mathrm{H} 40$.

1976, Geology of the northern part of the Toquima Range, Lander, Eureka, and Nye Counties, Nevada: U.S. Geological Survey Professional Paper 931, 49 p.

Nolan, T.B., Merriam, C.W., and Williams, J.S., 1956, The stratigraphic section in the vicinity of Eureka, Nevada: U.S. Geological Survey Professional Paper 276, 77 p.

Page, W.R., and Dixon, G.L., 1994, Modal analyses of selected Tertiary volcanic rocks from Nye and Lincoln Counties, Nevada: U.S. Geological Survey Open-File Report 94-151, 69 p.

Ross, R.J., Jr., 1970, Ordovician brachiopods, trilobites, and stratigraphy in east and central Nevada: U.S. Geological Survey Professional Paper 639, 203 p.

Shawe, D.R., 1988, Complex history of precious metal deposits, southern Toquima Range, Nevada, in Schafer, R.W., Cooper, J.J., and Vikre, P.G., eds., Bulk mineable precious metal deposits of the Western United States, Symposium Proceedings, Reno, Nevada: Geological Society of Nevada, p. 333-373.

-1995, Geologic map of the Round Mountain quadrangle, Nye County, Nevada: U.S. Geological Survey Geologic Quadrangle Map GQ-1756, scale 1:24,000.

1998, Geologic map of the Manhattan quadrangle, Nye County, Nevada: U.S. Geological Survey Geologic Quadrangle Map GQ-1775, scale 1:24,000.

Shawe, D.R., Marvin, R.F., Andriessen, P.A.M., Mehnert, H.H., and Merritt, V.M., 1986, Ages of igneous and hydrothermal events in the Round Mountain and Manhattan gold districts, Nye County, Nevada: Economic Geology, v. 81, p. 388-407.

Shawe, D.R., Naeser, C.W., Marvin, R.F., and Mehnert, H.H., 1987, New radiometric ages of igneous and mineralized rocks, southern Toquima Range, Nye County, Nevada: Isochron/West, no. 50 , p. 3-7.

Shawe, D.R., and Snyder, D.B., 1988, Ash-flow eruptive megabreccias of the Manhattan and Mount Jefferson calderas, Nye County, Nevada: U.S. Geological Survey Professional Paper 1471, 28 p.

Stewart, J.H., 1980, Geology of Nevada: Nevada Bureau of Mines and Geology Special Publication 4, $136 \mathrm{p}$. 